\title{
Investigating the Time Children with Autistic Spectrum Disorders Spend with Their Typically Developing Siblings
}

\author{
Mehmet Yavuz ${ }^{1, *}$, Pınar Şafak ${ }^{2}$ \\ ${ }^{1}$ Department of Special Education, Faculty of Education, Trakya University, Turkey \\ ${ }^{2}$ Department of Special Education, Gazi Faculty of Education, Gazi University, Turkey
}

Copyright $\bigcirc 2019$ by authors, all rights reserved. Authors agree that this article remains permanently open access under the terms of the Creative Commons Attribution License 4.0 International License

\begin{abstract}
This study aimed to investigate the time spent by the individuals with Autism Spectrum Disorder (ASD) with their siblings and to offer suggestions from the perspective of typically developing siblings so as to find how this might be improved. The study was carried out with the siblings presenting typical development of the individuals with ASD who were attending special education and rehabilitation centers in Istanbul. Ninety-three siblings with typical development participated in the study. The extended version of the questionnaire developed by Yavuz and Coşkun (2014) was used as the data collection tool of the study and the content analysis of the collected data was done. According to the results of the study, it was observed that the siblings play games, do other activities like leisure time activities outside the house with their siblings with ASD. The problems that arise when they spend time with their siblings with ASD outside their house are: communication problems, negative attitude of people, and other problems like behavior problems.
\end{abstract}

Keywords Autism Spectrum Disorder, Sibling Relationships, Family, Peers

\section{Introduction}

Autism spectrum disorder (ASD) is a neuro-developmental disorder that manifests itself in the early years of life, which affects the participation of the individual in daily life and which has limited and repetitive attention, behavior, activities and social interaction / communication deficiencies (Diagnostic and Statistical Manual of Mental Disorders -5 [DSM-5], 2013). Individuals with ASD experience developmental difficulties in general. Besides, they can exhibit social, communication problems and problem behaviors (Gray and Holden, 1992; Rao and Beidel, 2009). These problems experienced by individuals with ASD can adversely affect the family and cause significant stress on all family members (Gray and Holden, 1992; Rao and Beidel, 2009; Roeyers and Mycke, 1995; Sanders and Morgan, 1997; Senel and Akkök, 1996). In addition, the child's having ASD negatively affects families' housework, financial situation, mental health of the person who looks after the child, marital relationships and physical health of family members (Roeyers and Mycke, 1995; Şenel and Akkök, 1996). Families having a member with ASD can even quit going on a holiday, let alone think of going to anywhere (Montes and Halterman, 2008). All of these situations can significantly affect family members and function of the family (Gray and Holden, 1992; Rao and Beidel, 2009). All these conditions that affect the family naturally affect the siblings and the relationships among them (Roeyers and Mycke, 1995; Sanders and Morgan, 1997; Senel and Akkok, 1996).

The term sibling relationship includes physical actions, interactions and more subjective, cognitive and affective components of the relationship among siblings (Cicirelli, 1995). Sibling relations are affected by the age of the siblings, their level of social interaction and communication during childhood and their psychological characteristics during adolescence and adulthood (Orsmond and Marsha, 2007). There are some studies on how an individual's sibling's ASD affects his life in terms of positive and negative aspects. In the ones that indicate this situation affects sibling relations negatively, the sibling relations are very problematic for the siblings having typical development (Sinclair and Franklin, 2000). Studies show that siblings exhibit higher depression, loneliness and more behavioral problems (Hastings, 2003). Compared with other families, the siblings of the individuals with ASD had higher rates of communication and social 
disability (Piven, Palmer, Jacobi, Childress, and Arndt, 1997; Tsai et al. 2018), showing more behavioral problems than other children (Erden and Akçakın, 2001) and being more stressed out. (Gamble and McHale, 1989).

It is desirable that the sibling relations are good and the siblings spend time together. The good relations between the siblings will be beneficial for them all because the brothers learn new knowledge and skills, living together, a culture of reconciliation (Lamb and Sutton-Smith, 2014), making concessions to each other, convincing each other and caring for each other (Katz, Kramer and Gottman, 1992). In addition, siblings protect each other and are companions for each other (Shaffer, 2008). According to Rivers and Stoneman (2003), having a sibling with ASD has a positive impact on an individual's life. According to Ahmetoğlu (2004), an individual will not be able to keep up with the handicap of his sibling over time. The individual who adapts himself to the situation of his sibling with ASD develops a self-perception and controls himself better (Rivers and Stoneman, 2003).

There are several variables that affect the relationship among the individuals with ASD and their siblings positively and negatively. According to Hannah and Midlarsky (1999), the gender of the siblings, gender similarity, being younger or older, the age of the sibling with ASD and whether the care is given at home or outside the home affect their relationship. According to Morgan (1988), the impossibility, complexity and unpredictability of the explanation of the behavior of individuals with ASD affects their siblings more than the siblings of children with other disabilities, causing them to have psychological and harmony problems with their siblings. In addition, the degree to which the individual is affected by ASD is likely to affect sibling relationships.

It is of course difficult to conduct research examining all the aspects of the relationships of the individuals with ASD with their siblings. Therefore, we have limited knowledge about how the relationship of the individuals with their siblings with ASD throughout their lives is and how it changes over time (Orsmond, Kuo, and Seltzer, 2009). In spite of this, studies have examined the relationships of the individuals with their siblings with ASD in their existing state.

If we are to present these research in a developmental order, Bernabei, Camaioni and Levi, (1998) observed delay in the use of the gestures of the four-month-old children with ASD for playing and communicating with their siblings compared with their peers. In their research, Zwaigenbaum, Bryson, Rogers, Roberts, Brian and Szatmari (2005) observed that individuals need to address their siblings with ASD more during interactions. In their study examining the interaction of 12-month-old siblings, Mitchell, Brian, Zwaigenbaum, Szatmari, Smith and Bryson, (2006) found that children with ASD used less gestures than their peers. Kaminsky and Dewey (2001) reported that children with ASD had less interaction and showed less intimacy to their siblings. Considering the research of Bodur and Soysal (2004) in general, individuals with ASD were observed to play on their own rather than forming a relationship with their environment in the pre-school period. Knott, Lewis and Williams, (1995) observed the individuals with Down syndrome and ASD between the ages of two and 12 and their siblings at home settings. In the observations, it was seen that the siblings played games of imitation and rolling over, and did activities involving gross motor skills. It was also detected that the siblings of the individuals with ASD spent less time with their siblings than that of the individuals whose siblings have Down syndrome. Similarly, Pilowsky, Twentieth, Doppelt, Gross-Tsur and Shalev (2004) found that when compared the children with developmental delays with the individuals with ASD, the first ones spent more time with their siblings than the second group. In addition, the siblings of the individuals with ASD stated that they do not want to spend time with them because of their behavior problems and because they are embarrassed about them.

There are several studies investigating the relationships of the individuals with ASD with their siblings in the literature. Bernabei, Camaioni and Levi (1998) examined the social interaction, communication, language, functional and symbolic play skills of children with ASD between six and 24 months old with their siblings in home setting by watching their videos. Knott, Lewis and Williams (1995) studied sibling interactions using the autistic and Down syndrome checklist in natural home setting. Knott, Kaminsky and Dewey (2001) examined the relationships of the siblings aged between 8 and 18 of the individuals with ASD and Down syndrome. Pilowsky, Yirmiya, Doppelt, Gross-Tsur and Shalev (2004) interviewed the siblings who were at the age of sixteen and younger of the children with ASD and asked about their opinions regarding their siblings. Zoylan (2005) investigated the relationship of the individuals between the age of 12 and 23 with their siblings with ASD using a scale. Zwaigenbaum et al. (2005) observed both the interactions of the children with ASD with their siblings and that of the children with their typically developing siblings in early childhood using a checklist in a natural game setting. Mitchell et al. (2006) investigated the sibling relationship of the children with their siblings with ASD who were older than 24 months based on their parents' opinions. Aksoy and Yildırım (2008) studied the children aged between 0-17 who had typically developing siblings, learning disability, mental disability, cerebral palsy, mental and motor delay and ASD in terms of the relationship with their sibling and the acceptance of their siblings utilizing a scale. Orsmond, Kuo and Seltzer (2009) examined the relationship between the siblings older than 10 years old with adult individuals with ASD using a survey and telephone interviews. Üstdağ and Bumin (2014) investigated the effects of having siblings with cerebral palsy, encephalopathy, autism and diffused 
developmental disorder on the relationships and social inclusion of children from five to 13 year-old in group activities. This study aims to investigate how the siblings of individuals with ASD spend time at home and outside and offer solutions on how siblings can spend their time together better, because when there is a problem in the relations between the individual and his / her sibling with ASD, this situation will affect the family relations negatively (Higgins, Bailey and Pearce, 2005). In addition, if the sibling relationship is good, the sibling will take the responsibility of the sibling with ASD more willingly, which will eventually reduce the burden of the family (McHale, Jerry and Simeonsson, 1986). The thing that should not be forgotten in sibling relations is that when parents are unable to care for the individual with ASD, the sibling is also responsible for the life of his/her sibling (Orsmond, Kuo, and Seltzer, 2009). For all these reasons, it is very important for siblings to spend time together to get to know each other better since the siblings who know each other will get on well with each other better. For this reason, how siblings spent time was aimed to study by dividing it as weekdays and weekends. The reason for this distinction is the thought that the siblings will be busy at school, at work or with another activity on weekdays, and they will have more free time at weekends. Therefore, whether there is a difference between the activities done during the week and the weekend will be examined. From this point forth, the purpose of this study is to examine the time that the children spent with their siblings with ASD and to offer suggestions on how to spend their time better based on the siblings' opinions. Thus, the answers for the following questions were sought:

1. How do they spend time with their siblings with ASD outside home on weekdays and on the weekend?

2. What are the reasons why they do not spend time with their siblings with ASD outside home on weekdays and on the weekend?

3. What kind of arrangements can be made to have them spend more time with their siblings?

\section{Materials and Methods}

This section includes the research model, participants, data collection tools, data collection and data analysis.

\subsection{Research Design}

In this research, single screening model, one of the general screening models, was used. The screening model is a model that aims to describe a situation in the past or present as it is (Karasar, 2012). Screening models are models that allow studying different variables such as attitude, education, and opinion on a sample, which is taken from the population of a study. In the individual screening model, the examined variables are evaluated individually by determining their type or amount (Creswell, 2014).

\subsection{Participants}

Criterion sampling method, which is one of the purposeful sampling, was used in the research. Purposeful sampling is to select situations and individuals who have rich knowledge to reveal the problem of the research (Büyüköztürk et al., 2012). The criterion sampling method is used to investigate situations that meet certain predetermined criteria (Patton, 2014). The sample of this study is the siblings, who were attending at least secondary school, of 93 children with ASD attending 10 special education and rehabilitation centers in Istanbul in 2017-2018 academic year.

Present, as shown in Table 1, 50 out of 93 siblings were male $(53.8 \%)$ and 43 were female $(46.2 \%)$. The ages of the participants were between 11 and 25 years old. Seven of the participants $(7.5 \%)$ had no siblings other than the one with ASD; 37 of them had one (39.8\%), 24 of them had two $(25.8 \%), 15$ of them had three $(16.1 \%)$, nine of them had four $(9.7 \%)$ and one of them had six $(1.1 \%)$ siblings. As far as their education levels are concerned, five (5.4\%) attending secondary school, 19 (20.4\%) attending high school, $56(60.2 \%)$ attending university and 13 of them $(14 \%)$ work. While the number of the male siblings of the participants with typical development of this study is $64(68.8 \%)$, that of the female is 29 $(31.2 \%)$.

Table 1. The demographic information of the siblings

\begin{tabular}{|c|c|c|}
\hline Gender & $\mathrm{N}$ & $\%$ \\
\hline Male & 50 & 53.8 \\
\hline Female & 43 & 46.2 \\
\hline \multicolumn{3}{|l|}{ Age } \\
\hline Maximum & 25 & \\
\hline Minimum & 11 & \\
\hline Number of siblings & $\mathrm{N}$ & \\
\hline 0 sibling & 7 & 7.5 \\
\hline 1 sibling & 37 & 39.8 \\
\hline 2 siblings & 24 & 25.8 \\
\hline 3 siblings & 15 & 16.1 \\
\hline 4 siblings & 9 & 9.7 \\
\hline 6 siblings & 1 & 1.1 \\
\hline \multicolumn{3}{|l|}{ Education } \\
\hline Secondary school & 5 & 5.4 \\
\hline High school & 19 & 204 \\
\hline University & 56 & 60.2 \\
\hline Working & 13 & 14.0 \\
\hline \multicolumn{3}{|l|}{ Individuals with ASD } \\
\hline Male & 64 & 68.8 \\
\hline Female & 29 & 31.2 \\
\hline
\end{tabular}




\subsection{Data Collection Tools}

The extended version of the questionnaire developed by Yavuz and Coşkun (2014) was used as the data collection tool. There are 19 questions in the "Time spending tendency with the Handicapped Sibling" questionnaire developed by Yavuz and Coşkun (2014). For the current questionnaire, opinions from three special educators and three assessors were obtained. A pilot study was conducted with 15 people (five middle schools, high schools and university students each) to check if the questions are understandable. At the end of the pilot study, the questions were seen to be intelligible and, therefore, applied to the siblings without any change. The current survey consists of two parts and 24 questions. While the first part includes the demographic information of the participants, the second part includes the questions. Eight questions of the questionnaire are "yes - no type" and the other 16 questions are open-ended. The reason why this data collection tool was preferred is that it has open-ended questions. Open-ended questions were opted because they allow respondents to answer in any way they want without any limitation.

\subsection{Data Collection}

In order to collect the data, special education centers were visited in Istanbul. The siblings of the individuals with ASD who were attending at least secondary level schools were identified. Volunteerism was sought in the study. Face-to-face or telephone interviews were conducted with the siblings of these individuals and they were informed about the research. The participants were given face-to-face information on how to fill in the questionnaire. However, the questionnaires were sent to those who did not have a chance for face-to-face interviews and they were explained how to fill in the questionnaires by telephone.

\subsection{Data Analysis}

The content analysis method was utilized for the data gathered from "Time spending tendency with the Handicapped Sibling" questionnaire. Content analysis, which is one of the qualitative data analysis types, is generally used to analyze written and visual data (Silverman, 2001). In the content analysis, the raw data is analyzed and the concepts and themes that are similar to each other are brought together and presented in a way that the reader will understand (Yıldırım and Şimşek, 2008). In the content analysis, a deductive approach was used (Silverman, 2001). Content analysis is a method based on analyzing the depth of raw data and revealing sub-dimensions related to themes and the themes that are not predetermined by the researcher (Strauss and Corbin, 1990). Attention should be paid to when determining themes because people examining them should be able to reach the same categories (Silverman, 2001). In this study, the raw data was analyzed and divided into separate themes by both of the researchers. A code was given in accordance with the concepts reached from the themes (Strauss and Corbin, 1990). In the calculation made by both of the researchers, Miles and Huberman's (1994) [Consensus / (Consensus + Disagreement) x 100] formula was used. The reliability of the coder after the calculation was found to be $91 \%$. Because the coder reliability is over $80 \%$, it can be said that the coding is reliable (Miles and Huberman, 1994). When analyzing the data, instead of giving a name to the siblings with typical development, they were given codes such as N1, N2.

\section{Findings}

In this section, research findings were given. The findings were presented in tables descriptively.

As seen in Table 2, while 15 of the participants (16.1\%) said weekdays outside yes, to the question "Do you spend time with your sibling outside on weekends?" 77 (82.8\%) of the participants said no.

Table 2. Weekdays and weekend Brother out of house cases

\begin{tabular}{cccccc}
\hline Weekdays outside & $\mathrm{N}$ & $\%$ & Weekends outside & $\mathrm{N}$ & $\%$ \\
\hline Yes & 15 & 16.1 & Yes & 28 & 30.1 \\
\hline No & 77 & 82.8 & No & 65 & 69.9 \\
\hline
\end{tabular}

As evident in Table 3, the themes of the question "What would you like to make you spend more time with your sibling at home on weekdays?", "Game" (28.81\%), "Leisure time activities" (66.10\%) and "Other" (5.08\%). In the "Game" theme, participants gave answers like N36 "We play on the playground", N21 "Playing games", N33 "Playing with a ball", N23 "Playing in the garden", N15 "We play with the dog" and N12 "Various activities". As for the "Leisure time activities" theme, the answers obtained from the participants are as follows: N16 "We go shopping", N28 "We go to the cinema", N33 "We go to the park", N10 "We hang around", N41 "We go to a café", N2 "We go to malls", N34 "We drive around" and N10 "We go to the mosque". Finally, in the "Other" theme, the answers "We cannot go anywhere because of his/ her disability" and "We raise chicken" were given by N25 and N23, respectively. 
Table 3. What kind of activities do you do with your sibling while you spend time together outside on weekdays?

\begin{tabular}{|c|c|c|c|}
\hline Themes & Weekdays & Expression Frequency (f) & Expression Rate \\
\hline \multirow{6}{*}{ Game } & Playing on the playground & 6 & $35.29 \%$ \\
\hline & Playing with a ball & 4 & $23.53 \%$ \\
\hline & Playing in the garden & 3 & $17.65 \%$ \\
\hline & Playing with the dog & 2 & $11.77 \%$ \\
\hline & Doing various activities & 1 & $5.88 \%$ \\
\hline & & 1 & $5.88 \%$ \\
\hline \multirow{8}{*}{ Having Leisure Time } & Going shopping & 9 & $23.07 \%$ \\
\hline & Going to the cinema & 6 & $15.38 \%$ \\
\hline & Going to the park & 6 & $15.38 \%$ \\
\hline & Hanging around & 5 & $12.82 \%$ \\
\hline & Going to a café & 5 & $12.82 \%$ \\
\hline & Going to malls & 5 & $12.82 \%$ \\
\hline & Driving around & 2 & $5.12 \%$ \\
\hline & Going to the mosque & 1 & $2.56 \%$ \\
\hline \multirow{2}{*}{ Other } & We cannot go because of his/ her disability & 2 & $66.67 \%$ \\
\hline & Raising chicken & 1 & $33.33 \%$ \\
\hline
\end{tabular}

Table 4. What kind of activities do you do with your sibling while you spend time together outside on weekends?

\begin{tabular}{cccc}
\hline Themes & Weekends & Expression Frequency (f) & Expression Rate \\
\hline \multirow{3}{*}{ Game } & Playing games & 4 & $28.57 \%$ \\
& Playing with a ball & 4 & $28.57 \%$ \\
& Going to the playground & 4 & $28.57 \%$ \\
& Playing in the garden & 2 & $14.29 \%$ \\
\hline & Hanging around & 8 & $21.62 \%$ \\
& Going to the park & 5 & $13.51 \%$ \\
Having Leisure Time & Going to a café & 5 & $13.51 \%$ \\
& Going shopping & 4 & $10.82 \%$ \\
& Driving around & 4 & $10.82 \%$ \\
& Having a picnic & 4 & $10.82 \%$ \\
& Going to the amusement park & 2 & $5.40 \%$ \\
& Doing various activities & 2 & $5.40 \%$ \\
Other & Going swimming & 2 & $5.40 \%$ \\
& Cleaning my motorbike & 1 & $2.70 \%$ \\
\hline
\end{tabular}

As can be seen in Table 4, the themes of the question "What kind of activities do you do with your sibling while you spend time together outside on weekends?" are "Game" (24.14\%), "Leisure time activities" (63.79\%) and "Other" (12.07\%). The participants of this theme gave answers as follows: N3 "We play games together", N33 "We play with a ball" N36 "We go to the playground" and N23 "We play in the garden". As for the "Leisure time activities" theme, the answers obtained from the participants are N10 "We hang around together", N10 "We go to the park", N37 "We go to a café", N10 "We go shopping", N11 "We drive around", N16 "We go on a picnic", N23 "We go to the amusement park", N37 "We do various activities", N42 "We go swimming" and N5 "I clean my motorbike". Concerning the "Other" theme, "We go on a picnic" and "We cannot go anywhere because of his/ her disability" were given as answers by $\mathrm{N} 3$ and N25, respectively.

As it is seen in Table 5, 6 participants (40\%) said yes and 9 participants $(60 \%)$ said no to the question "Do you have problems when you spend time with your sibling outside on weekdays?" As for the "Do you have problems when you spend time with your sibling outside on weekends?" question, 12 participants (42.86\%) said yes and 16 participants $(57.14 \%)$ said no.

Table 5. Do you have problems when you spend time with your sibling outside on weekdays and weekends?

\begin{tabular}{cccccc}
\hline Weekdays & $\mathrm{N}$ & $\%$ & Weekends & $\mathrm{N}$ & $\%$ \\
\hline Yes & 6 & 40 & Yes & 12 & 42.86 \\
\hline No & 9 & 60 & No & 16 & 57.14 \\
\hline
\end{tabular}

As it was shown in Table 6, the themes of the answers given to the question "What kind of problems do you have when you spend time with your sibling outside at weekdays?" consist of "Communication" (12\%), "People's attitude" (12\%) and "Behavior problems" $(76 \%)$. In "Communication" theme, the participants" answer is N11 "He does not behave well". In "People's attitude" theme among the participants N12 said "We have problems with other people". In "Behavior problems" theme, the participants' answers are N15 "He is very vigorous", N32 "He has obsessive behaviors", N38 "He hits me when he gets angry", N2 "He makes me tag him", N7 "He wants to act independently" and N18 "He wants to do whatever he/she wants". 
Table 6. What kind of problems do you have when you spend time with your sibling outside at weekdays?

\begin{tabular}{cccc}
\hline Themes & Weekdays & $\begin{array}{c}\text { Expression Frequency } \\
\text { (f) }\end{array}$ & Expression Rate \\
\hline Communication problems & Not behaving well & 3 & $100 \%$ \\
\hline People's attitude & Having problems with other people & 3 & $100 \%$ \\
\hline & His/ her being very vigorous & 4 & $21.05 \%$ \\
& His/ her having obsessive behaviors & 3 & $15.78 \%$ \\
Behavior problems & His/ her hitting me when getting angry & 3 & $15.78 \%$ \\
& Having to tag him/ her & 3 & $15.78 \%$ \\
& His/ her acting independently & 3 & $15.78 \%$ \\
& His/ her desire to do whatever he/she wants & 3 & $15.78 \%$ \\
\hline
\end{tabular}

Table 7. What kind of problems do you have when you spend time with your sibling outside at weekends

\begin{tabular}{cccc}
\hline \multirow{2}{*}{ Themes } & Weekends & $\begin{array}{c}\text { Expression Frequency } \\
\text { (f) }\end{array}$ & Expression Rate \\
\hline \multirow{2}{*}{ Communication problems } & Not behaving well & 8 & $80 \%$ \\
& Communication & 2 & $20 \%$ \\
\hline \multirow{2}{*}{ People's attitude } & Having problems with other people People's not & 6 & $50 \%$ \\
& knowing autism & 6 & $50 \%$ \\
\hline & Being unable to control him/her & 7 & $23.33 \%$ \\
Behavior problems & Having to tag him/ her & 3 & $20 \%$ \\
& His/ her hitting me when getting angry & 3 & $10 \%$ \\
& His/ her running away & 3 & $10 \%$ \\
& His/ her spilling the meal over himself/ herself & 3 & $10 \%$ \\
& His/ her being misfit & $10 \%$ \\
& His/ her having obsessive behaviors & 3 & $10 \%$ \\
& His/ her getting annoyed of sounds and rustling & 2 & $6.67 \%$ \\
\hline Other & His/ her having physical disability & 2 & $100 \%$
\end{tabular}

As can be seen in Table 7, the themes of the answers given to the question "What kind of problems do you have when you spend time with your sibling outside at weekends?" are "Communication problems" (18.52\%), "People's attitude" (22.22\%), "Behavior problems" $(55.56 \%)$ and "Other" (3.7\%). The answers that were given by the participants in "Communication problems" theme are N11 "He/ she does not behave well" and N42 "Communication". Considering the "People's attitude" theme, the participants provided answers like N3 "We have problems with other people" and N4 "People outside do not know about autism". As for the "Behavior problems" theme, the answers given by the participants are N33 "I cannot control him/her", N4 "He/she makes me tag after him/her", N42 "He/she hits me when getting angry", N33 "He/she runs away from me", N3 "He/she spills the meal over himself/ herself in the café", N11 "He/she is a misfit person", N4 "He has obsessive behaviors", and N8 "He/she gets annoyed of sounds and rustling". Finally, in the "Other" theme, they gave answers like N17 "We cannot make it outside because of his/her physical disability".

As seen in Table 8, the themes of the question "What are your reasons of not spending time with your sibling outside on weekdays?" are "I have my own world" (8.41\%), "I have no time" (22.43\%), "Behavior problems" (49.53\%), "People's attitude" (7.48\%), "There is not a convenient environment" (4.67\%) and "Other" (7.48\%). The answers that were given by the participants in "I have my own world" theme are N76 "I usually hang around with my friends" and N88 "I play with a ball alone". When we take a look at the "I have no time" theme, the obtained answers are N66 "I study", N70 "I work", N81 "Our school schedule do not fit" and N73 "I have little time". As for the "Behavior problems" theme, the answers given by the participants are $\mathrm{N} 81$ "He/she causes trouble outside, too", N68 "I do not feel comfortable with my sibling outside", N85 "He/ she has many obsessive behaviors", N60 "He/she acts in the way he/she wants" and N89 "He/she becomes ill easily when we go out". Considering the "People's attitude", the answers are N72 "People are afraid of us" and N48 "People feel uncomfortable a lot because of my sibling". In the "There is not a convenient environment" theme N90 said "There is not a convenient environment". Finally, in the "Other" theme N74 said "It is difficult to go out once coming home from work". 
Table 8. What are your reasons of not spending time with your sibling outside on weekdays?

\begin{tabular}{|c|c|c|c|}
\hline Themes & Weekdays & $\begin{array}{c}\text { Expression } \\
\text { Frequency (f) }\end{array}$ & $\begin{array}{c}\text { Expression } \\
\text { Rate }\end{array}$ \\
\hline \multirow{2}{*}{ I have my own world } & I hang around with my friends & 6 & $66.67 \%$ \\
\hline & I play with a ball & 3 & $33.33 \%$ \\
\hline \multirow{4}{*}{ I have no time } & I am at school & 12 & $50 \%$ \\
\hline & I work & 6 & $25 \%$ \\
\hline & Our school schedule do not fit & 3 & $12.50 \%$ \\
\hline & I have little time & 3 & $12.50 \%$ \\
\hline \multirow{5}{*}{ Behavior problems } & $\mathrm{He} /$ she causes trouble outside, too & 22 & $41.51 \%$ \\
\hline & I do not feel comfortable & 20 & $37.74 \%$ \\
\hline & His/ her having obsessive behaviors & 5 & $9.43 \%$ \\
\hline & His/ her acting in the way he/she wants & 4 & $7.55 \%$ \\
\hline & His/her being ill easily when we go out & 2 & $3.77 \%$ \\
\hline \multirow{2}{*}{ People's attitude } & People's feeling scared & 5 & $62.5 \%$ \\
\hline & People's feeling uncomfortable & 3 & $37.5 \%$ \\
\hline Not having a convenient environment & Not having a convenient environment & 5 & $100 \%$ \\
\hline Other & It is difficult to go out once coming home from work & 8 & $100 \%$ \\
\hline
\end{tabular}

Table 9. What are your reasons of not spending time with your sibling at home on weekdays?

\begin{tabular}{|c|c|c|c|}
\hline Themes & Codes & Expression Frequency (f) & Expression Rate \\
\hline \multirow[t]{3}{*}{ I have my own world } & I hang around with my friends & 5 & $100 \%$ \\
\hline & I work & 14 & $29.17 \%$ \\
\hline & I do my homework & 14 & $29.17 \%$ \\
\hline \multirow[t]{4}{*}{ I have no time } & I study & 10 & $20.82 \%$ \\
\hline & I stay at school and study & 8 & $16.67 \%$ \\
\hline & I join etude group at school & 2 & $4.17 \%$ \\
\hline & His/her not talking to me & 8 & $50 \%$ \\
\hline \multirow[t]{3}{*}{ Communication problems } & His/her repeating words & 4 & $25 \%$ \\
\hline & Inability to communicate & 4 & $25 \%$ \\
\hline & His/her hitting me & 18 & $40.90 \%$ \\
\hline \multirow[t]{2}{*}{ Behavior problems } & His/her not listening to me & 13 & $29.55 \%$ \\
\hline & We do not get on well & 13 & $29.55 \%$ \\
\hline
\end{tabular}

When we examine Table 9, the themes of the answers to the question "What are your reasons of not spending time with your sibling at home on weekdays?" are "I have my own world" (6.19\%), "I have no time" (40.70\%), "Communication problems" (14.16\%) and "Behavior problems" (38.94\%). In the "I have my own world" theme, the obtained answer is N76 "I hang around with my friends". As regards to the "I have no time" theme, the participants' answers are N45 "I work", N34 "I do my homework", N13 "I study", N73 "I stay at school and study" and N86 "Since I study at a boarding school, I am not at home". Concerning the "Communication problems" theme, the answers are N55 "He/she cannot speak", N36 "He/she repeats words all the time" and N73 "We cannot communicate". Lastly, in the "Behavior problems" theme, the participants' answers are as follows: N37 "He/ she hits me" N81 "He/ she does not listen to me" and N31 "We do not get on well".

When analyzing Table 10, it can be seen that the themes of the answers to the question "What kind of incentives would you like to get to make you spend more time with your sibling outside on weekdays?" are "People's negative attitude" (30.71\%), "Convenient social activities" (4.72\%), "Financial support" (14.58\%), "Convenient physical environment" (31.5\%), "Enough time" (9.45\%), "I have no expectation" (3.94\%) and
"Other" (11.81\%). In "People's negative attitude" theme the answers of the participants are N18 "People need to gain consciousness", N80 "People should be more understanding" and N60 "Something needs to be done for people to embrace the handicapped". As for "Convenient social activities" theme, the answers obtained are N44 "Special activities should be organized by the government" and N35 "There could be courses like music courses just for autistic people". When analyzing the "Financial support" theme, the given answers are N13 "Having a well-paid job after graduation", N23 "Free swimming pool membership" and N25 "Battery-powered car". Regarding the "Convenient physical environment" theme, the obtained answers by the participants are N20 "It would be good if there was more green space", N63 "It would be great if there were more parks", N13 "Settings should be created where my sibling can interact with his/ her peers", N11 "There should be handicapped friendly service areas", N18 "It would be good if there were more physical amenities" and N17 "Making roads handicapped friendly". As for the "Enough time" theme, the provided answers are N38 "I do not have free time after work", N90 "I would take care of him/her if I had less homework" and N91 "since I study, I do not have time". In "I have no expectation" theme, the participants gave answers like: N50 "I have no expectation" and N13 "I do not want 
anything". Finally, in the "Other" theme, the obtained answers are N70 "I would want to work for the government for holiday opportunities" N40 "It would be good if teachers accompany us" N30 "I wanted to be in harmony with my sibling", N65 "We need support to take up sports" and N22 "I wanted to have a common sense of taste with my sibling".

Table 10. What kind of incentives would you like to get to make you spend more time with your sibling outside on weekdays?

\begin{tabular}{cccc}
\hline Themes & Weekdays outside & Expression Frequency (f) & Expression Rate \\
\hline People's negative & People's gaining consciousness & 15 & $38.46 \%$ \\
attitude & People's being more understanding & 15 & $38.46 \%$ \\
Convenient social & Activities help people to embrace the handicapped & 9 & $23.08 \%$ \\
activities & Special activities by the government & 3 & $50 \%$ \\
& Courses like music courses just for autistic people & 3 & $50 \%$ \\
Financial support & Having a well-paid job after graduation & 4 & $40 \%$ \\
& Free swimming pool membership & 4 & $40 \%$ \\
Convenient & Battery-powered car & 2 & $20 \%$ \\
physical & More green space & 9 & $22.5 \%$ \\
environment & More parks & 9 & $22.5 \%$ \\
& Creating settings where they interact with peers & 9 & $22.5 \%$ \\
Enough time & Service areas should be handicapped friendly & 9 & $22.5 \%$ \\
& & 2 & $5 \%$ \\
I have no & Having free time after work & 2 & $5 \%$ \\
expectation & Having less homework & 6 & $50 \%$ \\
& Having less school hours & 3 & $25 \%$ \\
& I have no expectation & 3 & $25 \%$ \\
Other & I do not want anything & 3 & $60 \%$ \\
& I would want to work for the government for holiday & 2 & $40 \%$ \\
& opportunities & 6 & $40 \%$ \\
& Teachers' accompanying us & & $20 \%$ \\
& I wanted to be in harmony with my sibling & 3 & $13.33 \%$ \\
& We need support to take up sports & 2 & $13.33 \%$ \\
& Having a common sense of taste with my sibling & 2 & $13.33 \%$ \\
\hline
\end{tabular}

Table 11. What kind of incentives would you like to get to make you spend more time with your sibling outside on weekends?

\begin{tabular}{cccc}
\hline Themes & Codes & $\begin{array}{c}\text { Expression } \\
\text { Frequency (f) }\end{array}$ & Expression Rate \\
\hline $\begin{array}{c}\text { People's negative } \\
\text { attitude }\end{array}$ & People's gaining consciousness & 15 & $44.12 \%$ \\
Convenient social & Activities help people to embrace the handicapped People's being & 15 & $44.12 \%$ \\
activities & more understanding & 4 & $11.76 \%$ \\
& Social activities that I can attend with my sibling & 10 & $55.56 \%$ \\
Financial support & Assistance for social environment & 5 & $27.78 \%$ \\
& Courses like music courses just for autistic people & 3 & $16.67 \%$ \\
Convenient & B would want to work for the government for holiday opportunities & 4 & $57.14 \%$ \\
physical & Battery-powered car & 3 & $42.86 \%$ \\
environment & Free medicine & 3 & $23.08 \%$ \\
& Convenient parks & 9 & $23.08 \%$ \\
Enough time & Creating settings where they interact with peers & 9 & $23.08 \%$ \\
& Enhancing environmental facilities & 9 & $23.08 \%$ \\
& Making public places handicapped friendly & 9 & $7.69 \%$ \\
& More green space & 3 & $33.33 \%$ \\
Other & Having a well-paid job after graduation & 6 & $33.33 \%$ \\
& Having a job with less work hours & 6 & $33.33 \%$ \\
& Having no courses & 6 & $15.38 \%$ \\
& Having a common sense of taste with my sibling Having a bicycle & 2 & $15.38 \%$ \\
\hline & Being in harmony & 2 & $15.38 \%$ \\
& Having a caretaker & 2 & $15.38 \%$ \\
& Teachers' accompanying us & 2 & $15.38 \%$ \\
\hline
\end{tabular}


As seen in Table 11, the themes of the answers to the question "What kind of incentives would you like to get to make you spend more time with your sibling outside on weekends?" are "People's negative attitude" (26.36\%), "Convenient social activities" (13.95\%), "Financial support" (5.43\%), "Convenient physical environment" (30.23\%), "Enough time" (13.95\%) and "Other" (2.33\%). In "People's negative attitude" theme the answers of the participants are N69 "People are afraid so they need to gain consciousness", N31 "Something needs to be done for people to embrace the handicapped" and N78 "It would be better if people become more understanding towards the autistic". In the "Convenient social activities" theme, the answers are N4 "There should be social activities that I can attend with my sibling", N35 "Assistance for social environment" and N35 "There should be courses like music courses just for autistic people". As for the "Financial support" theme, the answers given by the participants are N70 "I would want to work for the government for holiday opportunities", N16 "It would be nice if the state pays for medicine" and N17 "Battery-powered car". Concerning the "Convenient physical environment", the obtained answers are N30 "There should be more parks", N46 "Settings should be created where my sibling can interact with his/ her peers", N22 "It would be good if there were more physical amenities", N32 "Making public buildings handicapped friendly" and N70 "More green spaces". As for the "Enough time" theme, the provided answers are N67 "After graduating from school and getting a decent job, I will have more free time", N34 "I should have a job with less work hours" and N12 "I would take care of him/ her if I did not do a course". Lastly, in the "Other" theme, the answers are N14 "I wanted to have a common sense of taste with my sibling", N56 "It would be nice if we both have bicycles", N16 "Being in harmony", N22 "Having a caretaker" and N16 "Teachers" accompanying us".

\section{Discussion}

The majority of the participants in the study do not want to spend time outside the home because of the behavior problems of their siblings with ASD or because of the negative attitude of people. The siblings stated that they educate and study with their siblings with ASD when they spend time with them. According to Verte, Roeyers and Buysse (2003), siblings have an important role in the development and education of the child as well as all the other family members. Siblings' teaching a skill or a concept to their siblings who are handicapped contributes positively to their development (Karabulut \& Tavil, 2016; Taylor, 2001). When the literature was examined, Tekin (1999) was detected to have observed that typically developing siblings helped their handicapped siblings with learning the names of animals successfully.
One of the main problems that the siblings experience while spending time in and outside is the behavior problems of their siblings with ASD, which is also their chief reason for not wanting to spend any time with their siblings. Participants do not want to spend time with their siblings because they are afraid or unable to cope with these behavioral disorders. Behavioral problems are intensively observed in individuals with ASD (Siegel, 2003; Sucuoğlu, 2013). According to Hastings (2007), the siblings stated that they did not spend time because they are afraid that their siblings with ASD would hurt them. It is quite natural that children are unable to cope with their sibling with ASD who are especially older and physically stronger than themselves because of their intensive behavior problems. These behavior problems can be harmful for the sibling and other family members.

To spend more time with their siblings with ASD, siblings having typical development stated that they wanted to get education on how they would treat, how to deal with their behavior problems, how to spend time together and how to communicate with them. According to Girli (2004), it is necessary to offer training to typically developing siblings in order to help them communicate and support the various educational needs of their sibling with ASD. Bailey and Simeonsson (1988) concluded in their study that parents have problems in dealing with their children's behavior problems and need information about it. Karabulut and Tavil (2016) stated in their research that the siblings who teach are very happy both in the teaching period and teaching new skills to their siblings and added that they can spend more time with his brother in this way. With these trainings, the siblings will spend more time outside the home. This will help an individual with ASD learn new behaviors and participate in society as an independent individual.

The brothers also stated that they played games together in outside. Individuals with typical development can include their siblings with ASD to the games they play (Kaner, 2010; Taylor, 2001). Playing together will provide important learning opportunities for both the siblings with ASD and with typical development (Taylor, 2001). On the other hand, there are different opinions in the literature. According to these views, there are some studies indicating that typically developing individuals would not want to play with their siblings with ASD after a certain period of time even if they try playing with them at first due to their developmental delays, behavior problems or leaving the game. This situation prevents the children with ASD from gaining important skills (James and Egel, 1986).

Another activity that the participants do with their siblings with ASD in outside is the leisure activities. The "Convention on the Rights of the Handicapped", that was also signed by the Republic of Turkey, was accepted in the General Assembly of the United Nations on 13 December 2006. The convention suggests that it is 
mandatory for countries to organize leisure activities that the handicapped can participate in. Parallel to this, research indicates that the importance of teaching leisure time activities to handicapped individuals is increasing day by day. It is stated that making use of leisure time by choosing the activities they like doing will contribute to the health and happiness of the handicapped individuals. In addition to this, the typically developing individuals stated that there should be convenient activities to spend more time with their siblings with ASD (Majnemer, Shevell, Law, Birnbaum, Chilingaryan, Rosenbaum and Poulin, 2008). There are some findings in the literature supporting this view. Leisure activities will improve friendship by creating a positive interaction between individuals with and without handicaps. In this way, handicapped individuals learn to live independently by acquiring the knowledge and skills required at home and school settings without being alienated (King, Law, King, Rosenbaum, Kertoy and Young, 2003). Similarly, according to Etmek (2007), the participation of siblings in various activities will contribute to their future social relations, coping strategies and especially personality development significantly.

Inconvenient physical environment is one of the main problems that the siblings face when spending time with their siblings with ASD. In line with this fact, the participants want to have appropriate physical environment to spend more time with their siblings. According to Müftüoğlu (2006), handicapped individuals face with numerous obstacles in their daily lives starting from the buildings they live in. For example, according to Aykara (2015), the lack of an elevator in the apartment, where the handicapped person is residing, imprisons both the individual and his sibling and prevent them from going out as much as they want. For this reason, it is necessary to create areas where handicapped people can move comfortably (Aykara, 2015; Yavuz and Coşkun, 2014). Roads, pavements and protected parks and gardens, which are prepared in accordance with handicapped people, will allow them to leave their house and integrate with the community. Thus, siblings will spend more time together, which will cause a positive interaction between them.

Among the reasons for not spending time with their siblings with ASD are studying, doing a course, doing their homework and staying at school to study with friends. Siblings' going to different schools and, thus not being together is one of the problems that is encountered commonly (Üstdağ and Bumin, 2014). This situation prevents siblings from spending time together. Increasing the quality of the time that siblings spend in outside is considered important in the development of the relationship among them.

One of the reasons why siblings do not spend time with their siblings with ASD is that they work. The financial and spiritual burden of families with handicapped children is huge. In some families, the care of a child with a handicap may become unaffordable for these families due to economic problems (Parish, Cloud, Huh, and Henning, 2005; Zoylan, 2005). As the socio-cultural and economic level of the family decreases, the problems experienced increase as well (Stoneman, 2007). According to the findings of a study carried out by Aykara (2015), individuals who have a mentally handicapped sibling stated that even if they did not want to, they had to work to make a financial contribution to their family budgets. In order to overcome the problems easily and spend more time with their siblings, these individuals need financial support from the state (Yavuz and Coşkun, 2014).

One of the reasons for not spending time with their siblings with ASD is that they can sometimes be inflexible and desire to do whatever they want. According to Quin (2016), children with ASD exhibit certain behaviors for a very long time and many times and they can talk for hours on a specific subject. Children with ASD tend to do whatever they want and continue this behavior (Siegel, 2003). When these behaviors are interfered, they exhibit anger and behavior problems (Quin, 2016; Siegel, 2003).

Another reason for siblings' not spending time with their siblings with ASD is that they have communication problems. According to DSM V (2013), communication problems are one of the defining characteristics of children with ASD. In addition, in each of the children with ASD, language and speech disabilities are observed at various levels (Sucuoğlu, 2003). Communication skills are essential for the development of all children. Developing communication skills will make individual play games and live independently. In addition, they will become a member of the community by new experiences and participating in various activities (Law, 2002). It is one of the obstacles for siblings to spend time with them due to the deficiency in communication skills of children with ASD. For this reason, individuals with ASD cannot acquire most of the skills because of not interacting with their siblings from the first years on their life.

The participants stated another reason for not spending time with their siblings with ASD as "I have my own world or I do not spend a lot of time at home". According to Harris and Glassberg (2003), those who have siblings with ASD are confused and frustrated with their siblings' lack of interest in children's games. Later, they start to move away from their siblings with ASD and build new relationships with other people. In addition, some research are found in the literature indicating that typically developing siblings are embarrassed about their handicapped siblings and they do not want to appear in social settings with them (Onat Zoylan, 2005). However, siblings' spending time together and doing activities will positively affect their social relations, personality development and coping strategies (Etmek, 2007).

Considering another reason for the participants' not spending time with their siblings with ASD especially 
outside their home is the negative attitude of the people towards the handicapped. When we examine the literature, it can be seen that the society exhibits negative attitudes towards the handicapped, and they are seen as dependent, isolated from society and emotionally problematic individuals (Robinson, Martin and Thompson, 2007). On the other hand, individuals who have negative attitudes towards the handicapped have positive attitudes towards them after receiving the necessary training (McLeskey and Waldron, 2002). In particular, the siblings stated that in order for them to spend more time outside with their siblings, the attitudes of the people should be changed and they should know more about the individuals with ASD. Due to this negative attitude of the people, these individuals are not able to integrate with the society. For this reason, state institutions need to do the necessary work to inform the public. In cities, billboards can show videos or photos of people with ASD. In particular, informative seminars can be organized in schools to introduce groups of inadequacy.

This research is limited to the siblings participating in this study. Another limitation of the research is that in depth questions cannot be addressed because the questions in the questionnaire are open-ended. For example, referring to the siblings' activities outside the house as games prevented us from understanding what kind of games they played. For this reason, re-conducting this study using semi-structured interview method is thought to be useful.

\section{REFERENCES}

[1] Ahmetoğlu, E. (2004). Zihinsel engelli çocukların kardeş ilişkilerinin anne ve kardeş algılarına göre değerlendirilmesi. (Doktora Tezi, Ankara Üniversitesi Fen Bilimleri Enstitüsü), Ankara.

[2] Aksoy, A. B. ve Yıldırım, G. B. (2008). Farklı engel grubundan engelli kardeşe sahip çocukların kardeş ilişkileri ile kardeşlerini kabullenmeleri arasındaki ilişkinin incelenmesi. Educational Sciences: Theory ve Practice 8 (3), 751-779.

[3] APA (American Psychiatric Association) (2014). DSM-5 tanı ölçütleri başvuru el kitabı. (E. Köroğlu, Çev). Ankara: Hekimler.

[4] Aykara, A. (2015). Zihinsel engelli kardeşe sahip bireylerin yaşadıkları güçlüklerin sosyal rol kuramı açısından değerlendirilmesi. Toplum ve Sosyal Hizmet, 26(2), 87-104.

[5] Bailey, D. B. ve Simeonsson, R. J. (1988). Assessing needs of families with handicapped infants. The Journal of Special Education, 22(1), 117-127.

[6] Bernabei, P., Camaioni, L. ve Levi, G. (1998). An evaluation of early development in children with autism and pervasive developmental disorders from home videos: preliminary findings. Autism. 2,243-258.

[7] Bodur, Ş. ve Soysal, Ş. (2004). Otizmin erken tanısı ve önemi. Sürekli Tıp Eğitimi Dergisi, 13 (10), 394-398.

[8] Cicirelli, V. G. (1995). Sibling relationships across the life span. New York: Plenum Press.

[9] Creswell, J. W. (2014). Araştırma deseni: nitel, nicel ve karma yöntem yaklaşımları (Demir, S. B. Çev.).Ankara: Eğiten Kitap.

[10] Dunn, J. (1983). Sibling relationships in early childhood. Child Development, 54(4), 787-811.

[11] Erden, G. ve Akçakın, M. (2001). Otizmi olan çocuklar ve kardeşlerinin davranış sorunları ve kişilik özellikleri örüntüleri. Çocuk ve Gençlik Ruh Sağlığı Dergisi, 8 (3), 145-155.

[12] Etmek, K. F. (2007). Otizm ve kardeşler. özürlüler'07 kongre sergi ve sosyal etkinlikleri, 203.

[13] Gamble, W. C. ve McHale, S. M. (1989). Coping with stress in sibling relationships: A comparison of children with disabled and non-disabled siblings. Journal of Applied Developmental Psychology, 10, 353-373

[14] Gath, A ve Gumley, D. (1987). Retarded children and their siblings. Journal of Child Psychology and Psychiatry, 28 (5), 715-730.

[15] Girli, A. (2004). Otistik çocuklar ve aileleri aile eğitim programları: kuramsal yaklaşımlar ve uygulamalar. Işık Özel Eğitim Yayınları, İzmir.

[16] Gray, D. E. ve Holden, W.J. (1992). Psychosocial well-being among the caregivers of children with autismi. Australia and New Zealand Journal of Developmental Disabilities 18, 83-93.

[17] Hallahan, P. D. ve Kauffmann, M. J. (1998). Exceptional children introduction to special education. International Editions, New Jersey: Prentice Hall.

[18] Hannah, M. E. ve Midlarsky, E. (1999). Competence and adjustment of siblings of children with mental retardation. American Journa on Mental Retardation, 104, 22-37.

[19] Hansford, A. P. (2011). A sibling-mediated behavioral intervention for promoting play skills in children with autism. ((Master's thesis). Master of Science Graduate Program in Psychology, New Brunswick, New Jersey.

[20] Harris, S. L. ve Glasberg, B.A. (1994). Siblings of children with autism: A guide for families. Woodbine house Bethesda, MD.

[21] Harris, S. L. ve Glasberg, B.A. (2003). Siblings of children with autism: a guide for families. Bethesda: Woodbine House.

[22] Hastings, R. P. (2003). Brief Report: Behavior adjustment of siblings of children with autism. Journal of Autism and Developmental Disorders, 33, 99-104.

[23] Hastings, R. P. (2007). Longitudinal relationships between sibling behavioral adjustment and behavior problems of children with developmental disabilities. Journal of autism and developmental disorders, 37(8), 1485- 1492.

[24] Higgins, D. J., Bailey, S. R. ve Pearce, J. C. (2005). Factors 
associated with functioning style and coping strategies of families with a child with an autism spectrum disorder. Autism, 9(2) 125-137. DOI: 10.1177/1362361305051403.

[25] James, S., ve Egel, A. (1986). A direct prompting strategy for increasing reciprocal interactions between handicapped and non-handicapped siblings. Journal of Applied Behavior Analysis, 19, 173-186.

[26] Janson, K. ve Law, M. (2002). Siblings of Children with Special Needs. Physical ve occupational therapy in pediatrics, 22 (1), 73-78.

[27] Kaminsky, L. ve Dewey D. (2001). Sibling relationships of children with autism. J Autism Dev Disord 31, 399-410.

[28] Kaner, S. (2010). Aile katılımı ve işbirliği. B. Sucuoğlu (Ed.), Zihin engelliler ve eğitimi. (s. 352-378). Ankara: Kök Yayıncılık.

[29] Karabulut, A. ve Tavil, Y. Z. (2016). Zihin engellilere kardeş aracılığıyla sunulan öğretim programının oyun kurallarının öğretiminde etkililiği. Abant İzzet Baysal Üniversitesi Eğitim Fakültesi Dergisi, 16(3), 884-901.

[30] Katz, L. F., Kramer, L. ve Gottman, J. M. (1992). Conflict and emotions in marital, sibling, and peer relationships. Conflict in child and adolescent development, 122-149.

[31] King, G., Law, M., King, S., Rosenbaum, P., Kertoy, M. K., ve Young, N. L. (2003). A conceptual model of the factors affecting the recreation and leisure participation of children with disabilities. Physical and occupational therapy in pediatrics, 23(1), 63-90.

[32] Kinney, V. B., ve Coyle, C. P. (1992). Predicting life satisfaction among adults with physical disabilities. Archives of Physical Medicine and Rehabilitation, 73, 863-869

[33] Knott, F., Lewis, C. ve Williams, T. (1995). Sibling interactions of children with learning disabilities: a comparison of autism and Down's syndrome. J Child Psychology Psychiatry 56:965-97.

[34] Knott, F., Lewis, C., ve Williams, T. (1995). Sibling interaction of children with learning disabilities: a comparison of autism and Down's syndrome. Journal of Child Psychology and Psychiatry, 36, 965-976.

[35] Karasar, N. (2005). Bilimsel araştırma yöntemi. Ankara: Nobel Yayınevi.

[36] Korkmaz A. (2008). Özel eğitim alan zihinsel engelli çocukların kardeşleri ile ilişkilerinin değerlendirilmesi. (Yüksek lisans tezi, GATA Sağlık Bilimleri Enstitüsü), Ankara

[37] Lamb, M. E. ve Sutton-Smith, B. (2014). Sibling relationships: Their nature and significance across the lifespan. Psychology Press. New York: Taylor ve Francis.

[38] Majnemer, A., Shevell, M., Law, M., Birnbaum, R., Chilingaryan, G., Rosenbaum, P. ve Poulin, C. (2008). Participation and enjoyment of leisure activities in school-aged children with cerebral palsy. Developmental Medicine and Child Neurology, 50(10), 751-758.

[39] McHale, S. M., Jerry, S. ve Simeonsson, R. J. (1986). Sibling Relationships of Children with Autistic, Mentally Retarded, and Nonhandicapped Brothers and Sisters.
Journal of Autism and Developmental Disorders, 16(4) 399-413

[40] McLeskey, J. ve Waldron, N. (2002). Inclusion and school change: Teacher perceptions regarding curricular and instructional adaptations. Teacher Education and Special Education, 25(1), 41-54.

[41] Milletlerarası Sözleşme, (2009). T.C. resmi gazete, 25874, 27288, 14 Temmuz 2009.

[42] Mitchell, S., Brian, J., Zwaigenbaum, L, Szatmarı, P., Smith, I. ve Bryson, S. (2006). Early language and communication development of infants later diagnosed with autism spectrum disorder. J Dev Behav Pediatr 27, 69-S78.

[43] Molinaro, M., Morelli, P., De Gregori, M., De Gregori, S, Giardini, I., Tordato, F., Monzillo, V., Pocaterra, D. ve Casari, E. (2018). Efficacy of intraventricular amikacin treatment in pan-resistant Pseudomonas aeruginosa postsurgical meningitis. Infect Drug Resist. (3)11:1369-1372. doi: 10.2147/IDR.S169271.

[44] Montes, G. ve Halterman, J. S. (2008). Psychological functioning and coping among mothers of children with autism: A population-based study. Pediatrics, 119, 1040-1046.

[45] Morgan, S. B. (1988). The autistic child and family functioning: A developmental family-systems perspective. Journal of Autism and Developmental Disorders, 18, 263-280.

[46] Müftüoğlu, U. (2006). Tekerlekli sandalye kullanan bedensel engellilerin kentsel mekanları kullanım olanaklarının Trabzon kent merkezi örneği üzerinde incelenmesi. (Yüksek lisans tezi, Karadeniz Teknik Üniversitesi Fen Bilimleri Enstitüsü), Trabzon.

[47] Onat Zoylan, E. (2005). Engelli kardeşi olan ve olmayan bireylerin kardeş ilişkilerinin belirlenmesi. (Yüksek lisans tezi Abant İzzet Baysal Üniversitesi Sosyal Bilimler Enstitüsü). Bolu.

[48] Orsmond, G. I. ve Marsha, M. S. (2007). Siblings of individuals with autism spectrum disorders across the life course. Mental Retardation and Developmental Disabilities Research Reviews 13,313-320.

[49] Orsmond, G. I. ve Seltzer, M. M. (2000). Brothers and sisters of adults with mental retardation: The gendered nature of the sibling relationship. American Journal on Mental Retardation, 105, 486-508.

[50] Orsmond, G. I., Kuo, H. ve Seltzer, M. M., (2009). Siblings of individuals with an autism spectrum disorder: Sibling relationships and wellbeing in adolescence and adulthood. Autism, 13(1), 59-80. doi: 10.1177/1362361308097119.

[51] Parish, S. L., Cloud J. M., Huh, J. ve Henning A. N. (2005). Child care, disability, and family structure: Use and quality in a population-based sample of low-income preschool children. Child Youth Serv Rev, 27(8), 905-919.

[52] Pilowsky, T., Yirmiya. N., Doppelt, O., Gross-Tsur, V. ve Shalev, R. S. (2004). Social and emotional adjustment of siblings of children with autism. J Child Psychology Psychiatry 45:855-865.

[53] Piven, J., Palmer, P., Jacobi, D., Childress, D. ve Arndt, S. 
(1997). Broader autism phenotype: Evidence from a family history study of multiple-incidence autism families. American Journal of Psychiatry, 154, 185-190.

[54] Rao, P. A. ve Beidel, D. C. (2009). The impact of children with high-functioning autism on parental stress, sibling adjustment, and family functioning. Behavior Modification, 33(49), 437-451.

[55] Reagon, K. A., Higbee, T. S. ve Endicott, K. (2006). Teaching pretends play skills to a student with autism using video modeling with a sibling as model and play partner. Education and Treatment of Children, 29, 517-528.

[56] Rivers, J.W. ve Stoneman, Z. (2003). Sibling relationships when a child has autism: Marital stress and support coping. Journal of Autism and Developmental Disorders, 33, 383-394.

[57] Robinson, C., Martin, J. ve Thompson, K. (2007). Attitudes towards and perceptions of disabled people - Findings from a module included in the 2005 British Social Attitudes Survey. Disability Rights Commission.

[58] Roeyers, H. ve Mycke, K. (1995). Siblings of a child with autism, with mental retardation, and with a normal development. Child: Care, Health and Development 21, 305-19.

[59] Sanders, J. L. ve Morgan, S. B. (1997). Family stress and adjustment as perceived by caregivers of children with autism or down syndrome: implications for intervention. Child and Family Behaviour Therapy 19 (4), 15-32.

[60] Seligman, M. (1983). Sources of psychological disturbance among siblings of handicapped children. Personnel and Guidance Journal, 61 (9), 529-531.

[61] Senel, H. G. ve Akkok, F. (1996) 'Stress levels and attitudes of normal siblings of children with disabilities. International Journal for the Advancement of Counselling $18,61-8$.

[62] Shaffer, D. (2008). Social and personality development. Cengage Learning

[63] Siegel, B. (2003). Helping children with autism learn: treatment approaches for parents and professionals. New York: Oxford University.

[64] Stoneman Z. (2007). Examining the Down syndrome advantage: Mothers and fathers of young children with disabilities. J Intellect Disabil Res, 51(12), 1006-1017.

[65] Sucuoğlu, B. (2003). Otizm ve otistik bozukluğu olan çocuklar. Ataman A. (Ed.). Özel gereksinimli çocuklar ve özel eğitime giriş (s. 400-410). Ankara: Gündüz Eğitim Yayınc1lik.

[66] Sucuoğlu, B. (2013). Otizm spektrum bozukluğu olan çocukların problem davranışlarının azaltılması. Tekin-iftar E. (Ed.).Otizm spektrum bozukluğu olan çocuklar ve eğitimleri. Ankara: Vize.

[67] Sucuoğlu, B. (2013b). Otizm spektrum bozukluğu olan çocukların değerlendirilmesi. Tekin-iftar E. (Ed.) Otizm spektrum bozukluğu olan çocuklar ve eğitimleri. Ankara: Vize.

[68] Taylor, B. A. (2001). Teaching peer social skills to children with autism. In C. Maurice, G. Green, ve R. M. Foxx (Eds.), Making a Difference: Behavioral Intervention for Autism (s. 83-96). Austin, TX: Pro-Ed.

[69] Tekin, E. (1999). Zihin özürlü çocuklara kardeşleri aracılığıyla sunulan dört saniye sabit bekleme süreli öğretimin ve eşzamanlı ipucuyla öğretimin etkililiklerinin ve verimliliklerinin karșılaștırılması. Unpublished $\mathrm{PhD}$ Thesis. Anadolu Üniversitesi, Soysal Bilimler Enstitüsü, Eskișehir.

[70] Tsai, P. T., Rudolph, S., Guo, C., Ellegood, J., Gibson, J. M., Schaeffer, S. M., Mogavero, J., Lerch, J. P., Regehr, W. Ve Sahin, M. (2018). Sensitive periods for cerebellar-mediated autistic-like behaviors. Cell Reports, $25,357-367$.

[71] Üstdağ, E. L. ve Bumin, G. (2014). Engelli çocuklar ve kardeşleri için uygulanan grup aktivitelerinin toplumsal katılım ve kardeș ilișkileri üzerine etkisinin incelenmesi: pilot çalışma. Ergoterapi ve Rehabilitasyon Dergisi, 2(3), 141-147.

[72] Verte, S., Roeyers, H. ve Buysse, A. (2003). Behavioural problems, social competence and self-concept in siblings of children with autism. Child: Care, Health and Development, 29, 193-205.

[73] Yavuz, M. ve Coşkun, İ. (2014). Normal gelişim gösteren bireylerin zihinsel engelli kardeşiyle vakit geçirme durumu. Turkish Studies, 9(8)295-313. Doi Number: http://dx.doi.org/10.7827/TurkishStudies.7215

[74] Zoylan, E. O. (2005). Engelli kardeşe sahip olan ve olmayan bireylerin kardeş ilişsilerinin belirlenmesi. (Yüksek lisans tezi, Abant İzzet Baysal Üniversitesi Sosyal Bilimler Enstitüsü). Bolu.

[75] Zwaigenbaum, L., Bryson, S., Rogers, T., Roberts, W., Brian, J. ve Szatmari P. (2005). Behavioral manifestations of autism in the first year of life. International Journal of Developmental Neuroscience, 23,143-152. 